\title{
The Weaponization of Digital Media in the Service of Authoritarianism
}

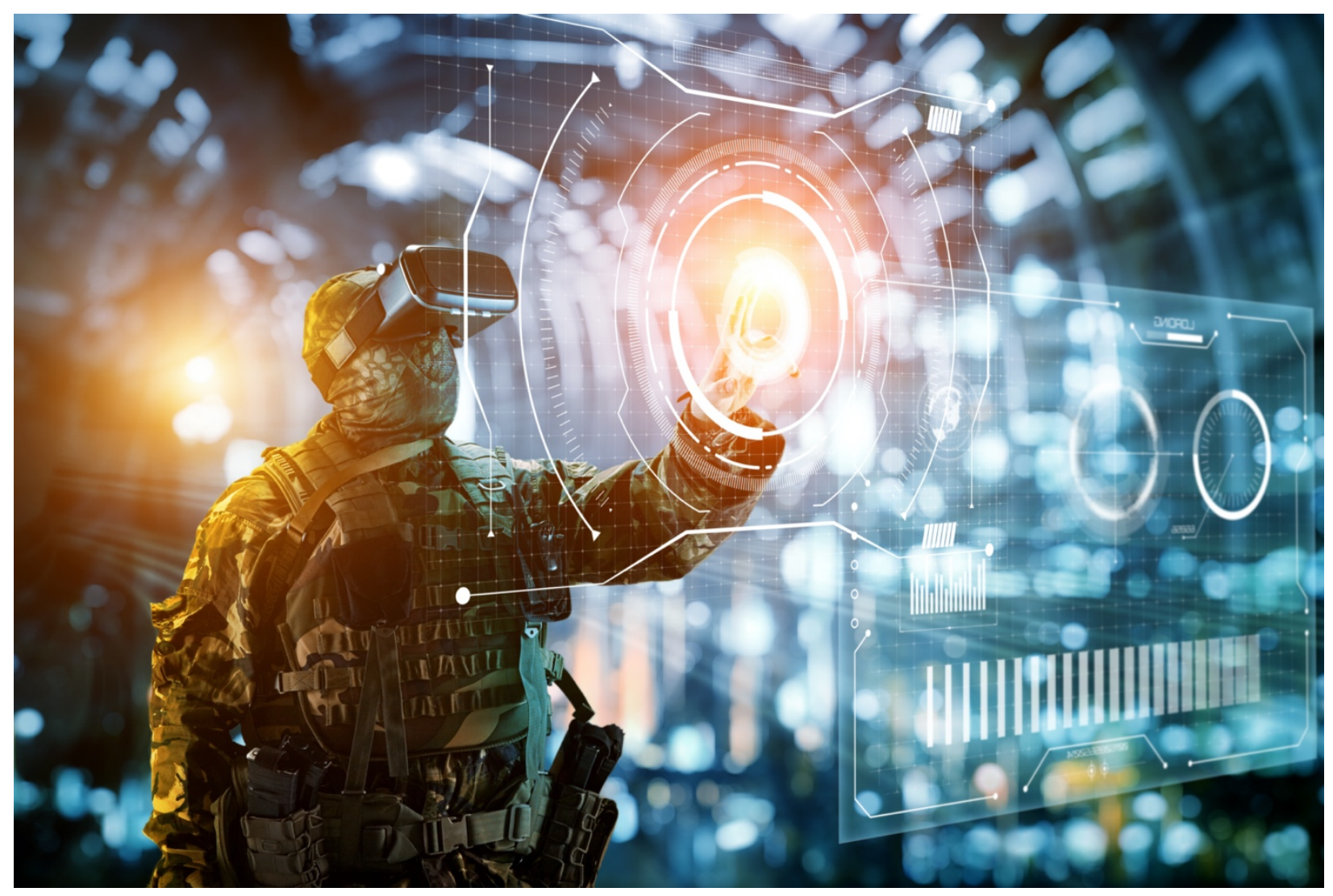

\section{Olga Gerasimenko}

Department of Political Science \& International Relations

University of Delaware

Symposium on Authoritarianism and Good Governance

Muqtedar Khan (Ed.)

International Institute of Islamic Thought | February 2021

DOI: http://doi.org/10.47816/02.001.25 
Ever since the Arab Spring, the democratizing and liberating effects of digital and social media have been in the spotlight of academics and journalists.

The Internet and new media brought along a "fundamental structural change," one that Carl Builder, a military affairs analyst, predicted would shift the balance of power away from states and in favor of individuals and civil society. ${ }^{1}$ The transformative power of information and activism enhanced by the new technologies raised hopes of democratization in many nations. As social and digital media became essential to the functioning of civil society, political campaigns, and international relations, Larry Diamond and Marc Plattner (2012) claimed that the new practice of information exchange blurred borders between information and action. ${ }^{2}$ New technologies, they argued, demonstrated potential to "liberate societies from autocracy."3

Naturally, governments have been learning and attempting to adapt to technological changes throughout history. An authoritarian state, which has a variety of instruments of coercion, surveillance, and control at its disposal, can retaliate by curbing the flows of information through censorship of content and persecution of the opposition. China is a striking example of one such regime. As one of the most censored countries, it does not allow access to such websites as Google, YouTube, Facebook, Wikipedia, as well as major Western media websites, including The New York Times, CNN, and BBC as of 2021. Rebecca MacKinnon (2012) coined the term "networked authoritarianism" to describe the way Beijing has dealt with the democratizing effect of digital 
communications and internet-based information flows.

Once authoritarian regimes recover from the initial shock of the new power of civil society to mobilize, organize, and protest, they start to invest in not just countering the new advantage but also reasserting their authority and control. Governments possess considerably more resources than the civil society. Judicious and strategic allocation of resources in technology and capacity building of state security institutions enables governments to get ahead in the new media game. Now we see authoritarian governments use the same new media to manufacture consent, shape public opinion, and legitimize their policies.

Some of the resources helpful for spreading disinformation and propaganda are readily available to any interested entity. For example, Facebook algorithms created for advertisement purposes can be used by government surveillance and control. The tools that put users into categories based on personal and political characteristics in specific geographic areas are publicly accessible and within reach of foreign intelligence agencies and law enforcement. Facebook has been actively used in political campaigns in non-democratic states. For instance, Facebook became a vessel for spreading aggression and false information during the Philippine President Duterte's election campaign in 2016. After the election, Duterte used Facebook to target and jail opponents and journalists. 4

Similar cases are available in the democratic world as well. Spreading disinformation was a major strategy of the Trump campaigns. The campaigns also utilized Facebook to disseminate micro-targeted ads designed to sow confusion and delegitimize anyone 
criticizing Trump.5 The ubiquity of such methods illustrate the reality of the rise of online (or digital) authoritarianism, a phenomenon described in the Freedom House project titled, Freedom on the Net, which reported continuous decline of Internet freedom in the US and across the world. The 2019 report also outlined the use of media platforms as "instruments for political distortion and societal control." 6

The loss of reelection by Trump may suggest that the scale or intensity of his campaign's disinformation operation was not sufficient to ensure victory for him. However, it would be fairer to attribute this outcome to the work of the independent media organizations as well as the strength of the US democratic institutions. The countries that have neither of the two see different political developments. China and Russia are two obvious examples of authoritarian states that seek to challenge US dominance in the world arena and are heavily investing in the new media to achieve that goal.

China, ruled by the Communist Party, is the world's second-largest economy and a rising global power. Russia has been under the Putin regime for over twenty years. Both are nuclear powers and permanent members of the United Nations Security Council. China is the world's largest state by population where as Russia is the biggest in size. Both Russia and China spend a considerable portion of their budgets on control of the media, but their methods and ability to reach global audiences vary.

\section{China and the Control of Information and Media}

China's foreign policy strategy and budget have long included "media warfare." After the 2008 Summer Olympics in Beijing, the government 
allocated 6.6 billion dollars for global media expansion. China has been heavily investing in foreign-language media, 7 as well as spending tens of millions of dollars solely on influencing the US. ${ }^{8}$ In pursuit of a "new world media order," in addition to global disinformation campaigns conducted through the social media and messaging apps such as WeChat, China organized and fully funded international media summits as well as foreign journalists' trips and training in China with the purpose of securing favorable coverage; it also financed pro-China ads in the Western media and made contentsharing deals with credible media organizations in order to push for proChina coverage. 9

In terms of freedom of expression, China was rated as fifth most censored country by the Committee to Protect Journalists in
2019 and is one of the world's top jailers of journalists. ${ }^{10}$ The Cyberspace Administration of China, founded in 2014, controls which content is allowed on the Internet in China and tracks down violators who face consequences and prosecution. Internet censorship is considered a top priority by the Chinese government. The government dictates the way information is framed, while the press does not have any proper legal protection and the courts are controlled by the government. The authorities oversee the means of production and set the rules for Internet service providers. ${ }^{11}$ China's low press freedom rankings and total control over journalists did not prevent the government from calling the country a "true democracy and a champion of human rights" in a white paper published on the $70^{\text {th }}$ anniversary of the People's Republic of China (PRC). ${ }^{12}$ 
Such statements are an example of a blatant propaganda approach by the Chinese government, possible due to complete lack of accountability.

For the last twenty years, virtually all online news in China comes from one source-the Xinhua News Agency, which has been the Party's mouthpiece since before the establishment of the PRC itself. 13 People's Daily is the largest newspaper in the country and is affiliated with the Party. The online version of the newspaper claims to reach 258 million people per day in over 200 countries. ${ }^{14}$ As most of the alternative sources of information in China are banned, the official media play the main role in presenting any news to the people. For instance, the mostly peaceful 2019-2020 Hong Kong protests were portrayed as violent by the state media, which also blamed them on "foreign hostile forces" such as the US. 15 Similarly, the Chinese newspapers preferred to downplay the severity of the spread of COVID-19 in China during early 2020 and strived to shift the focus elsewhere. ${ }^{16}$ In the absence of alternate sources, such portrayals alone shape public opinion about these events and the government faces no challenge to its worldview or to the policies it adopted to address both the protests and the pandemic.

It is safe to say that the main and only purpose of online media in China is to shape public opinion and assist in preserving the regime. The government views controlling the online conversation as essential for remaining in power. The chief editor of People's Daily defined anything less than full control over the media as a potential "historic mistake."17 While the statecontrolled media in China are highly influential domestically due to lack of 
competition and alternate perspectives, they are less successful at the international level because of the problematic image of China. This does not stop China from attempting to boost its social media presence and create at least an appearance of popularity on Twitter and Facebook, which are blocked in China. The number of followers of People's Daily Englishlanguage Facebook and Twitter pages are rapidly growing, even though there is lack of evidence that the followers' accounts are real. In addition to boosting an image of growth, artificial accounts and bot activity may help generate visibility and cause content to become trending. ${ }^{18}$

\section{Russia and the Weaponization of}

\section{Media}

In contrast to China, Russia invests considerably more in the quality of propaganda and disinformation campaigns. Russia has a long history of censorship and propaganda. After coming to power, Putin made media control one of the regime's priorities. Unlike China, Russia's methods do not entail creating an information vacuum for the population. Rather, Russia is focusing on developing its own informational dimension, which would shape and dominate Russians' worldview without severely limiting their access to the rest of the Internet (although Russia does ban some websites and interferes with the work of Western social media websites). The domestic successes of Russia's propaganda machine, which helped preserve Putin's high ratings despite a poor social and economic situation in the country, emboldened the regime to grow increasingly ambitious about shaping the views of people and entities outside of Russia and the Russianspeaking world. 
While the 1990 s were the freest period for the Russian press, by mid2000s the state had garnered control over $70 \%$ of the electronic media. The government took freedom and independence away from the media organizations with the help of a host of financial and administrative measures, such as fines and sanctions, legal action against media organizations and individual journalists on the basis of alleged libel, non-compliance with safety regulations, together with banning the undesirable media representatives from accessing information and public events. Additionally, in continuation of the Soviet legacy, self-censorship and violence against journalists persisted and then was taken to a new level. 19 The political discourse in Russia deteriorated and became permeated with Putin's own cynical vision of reality and interpretation of events. ${ }^{20}$ The discourse was largely built around promoting Russia’s new “national idea," 21 which laid the groundwork for the anti-Western rhetoric and elevation of Russia's projected unique experience and moral standing. In order to achieve these goals, Putin's regime made full use of the new technologies. The media budget in Russia is significant: in recent years Russia has been spending over a billion dollars per year on mass media, increasing it to 1.25 billion dollars in 2020. ${ }^{22}$ Russia's state-controlled media are considered "strategic national priorities" and are protected by the government. 23

One of the media that enjoys generous funding and operates globally is RT, the organization that started as a television channel, "Russia Today," in 2005 and has grown into an influential digital media outlet that reaches out to hundreds of millions of people across the world and offers coverage in several 
languages. RT's reputation as the government's mouthpiece and "the Russian government's main weapon in an intensifying information war with the West" has raised concerns among experts. $24 \mathrm{RT}$ is summoned to broadcast Russia's vision of the global affairs and offer "alternative perspectives."25 The term "information war" is actively used in the Russian media space, which provides further evidence that information, or disinformation, is purposefully weaponized and employed to serve the regime. The Russian media use a variety of tactics, including elaborate storytelling, delegitimization and subtle negative coverage, along with manipulation of vague but emotionally appealing concepts such as morality. Whether the goal is to cause confusion or distraction, suppress voters, or to manipulate public opinion or political elites' views, both the official media like
RT and the covert operations performed by troll factories represent a sizeable and dangerous opponent of the democratic forces and structures in the world as they strive to dominate the global discourse and succeed in its disruption.

Russian propaganda and disinformation campaigns that fuel its information war against the West are the centerpiece of Russia's so-called hybrid warfare-a range of methods used by the government to promote its agenda in international affairs. These techniques also include conventional warfare, private military companies, intelligence and espionage, economic tools, diplomacy, lawfare, and cyberwarfare. 26

The Russian regime can be pursuing a number of goals by using a combination of strategies. The lack of military strength and weakening resource-based economy, which is under 
sanctions, are compensated by

cyberattacks that can both destabilize

the target and yield intelligence results.

Lawfare refers to the way Russia

manipulates the international law and

creates justifications for military

intervention-as happened in Ukraine

and Georgia. Specifically, the regime

justified the intervention in both cases

by the need to protect ethnic Russians

living there. In the aftermath of the 2014

Ukrainian Revolution, Russia held a

referendum in Crimea, which was

deemed illegal by most countries, in

order to justify the annexation of the

peninsula. Additionally, using hybrid

warfare allows Russia to achieve certain

objectives in a more clandestine way

without a more open confrontation. 27

The information warfare is

critical for each of the branches of the

"Hydra." The propaganda machine

works to manufacture consent for a war

from the Russian population and continued support of the regime, which includes "patriotic education." The internationally-oriented propaganda strives to find support among the foreign governments, elites, and people in general, while simultaneously attempting to undermine leadership of the West and liberal values.

Russian hybrid warfare came into play during the interference in the 2016 US presidential election. In an attempt to help Donald Trump win the election, hackers sponsored by the Russian government conducted cyberattacks against the Democratic National Committee and targeted voterregistration systems. Russia also provided financial assistance by funneling illegal money through the National Rifle Association. In addition, Kremlin-employed and managed Internet trolls and bots launched social media-based campaigns aimed at suppressing voters and sowing discord 
in the US society. The campaign

conducted by the Russia's so-called troll

factory succeeded in reaching millions of

Americans and engaging them in

various ways. 28 The US Senate

Intelligence Committee confirmed

"extensive activity" by Russia to meddle

with the election and called for the US to

strengthen its defense capabilities. 29 In

the months prior to the 2020 election

the US intelligence warned about "a

range of measures" used by Russia to

intrude once again. 30 It was

subsequently reported that the

interference was significantly less

successful this time, for a few possible

reasons, including the strengthened US

infrastructure, decreased motivation by

Russia, and the fact that President

Trump himself became the largest

source of disinformation during the

election season. 31

\section{Conclusion}

The development and wide use

of new media raised hopes for a more

democratic future of the world. The

scholars and journalists underscored the

democratizing effects of the new media

and technologies, which they predicted

could liberate societies and dismantle

autocratic regimes. Today's realities,

however, demonstrate that many

authoritarian states largely succeeded in

adapting to the situation and learned to

utilize the new media to their own

advantage. The authoritarian

governments, like those of Russia and

China, strive to acquire new

technologies and heavily invest in new

media, enabling them to assert their

power and maintain control. Even if it

takes a government longer to learn and

adapt than it takes civil society, the

resources that a government possesses

and is willing to spend on boosting its

authoritarianism can be vast. Both the 
Russian and the Chinese regimes have sent clear signals that their ultimate goal is the monopoly on information at the domestic level and domination at the international level. The West should take this information war seriously.

\section{AUTHOR BIO}

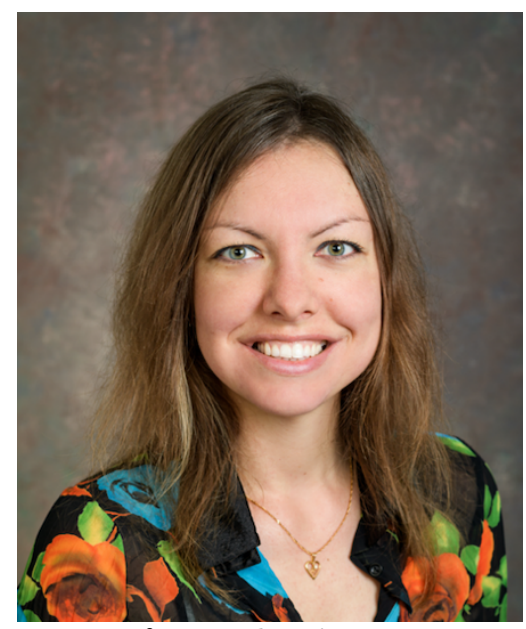

\section{Olga}

Gerasimenko is a recent $\mathrm{PhD}$ graduate of the Department of Political Science and International Relations at the University of Delaware. Her research interests include digital media, authoritarianism, political rhetoric, disinformation campaigns, and cybersecurity. Her dissertation entitled "The War of Words? The Role of New
Media in State Propaganda and Foreign Policy: The Cases of Russian, Chinese, and Turkish Media News Coverage" focused on explaining how nondemocratic states use the statecontrolled media to influence international public opinion, generate support for and legitimize their policies and actions, and to shape international discourses on critical issues. Olga also holds an MA (2015) in political science and international relations from the University of Delaware, an MA (2013) in political science from Ohio University, and a specialist degree (2011) from the Far Eastern Federal University (Vladivostok, Russia) in Chinese studies and international relations and foreign policies in East Asia. Olga has taught courses on global politics, politics and the media, and American politics. 


\section{END NOTES}

${ }^{1}$ Carl H. Builder, "Is It a Transition or a Revolution?," Futures 25, no. 2 (1993): 155-57, https://doi.org/10.1016/o0163287(93)90161-L.

2 Larry Jay. Diamond and Marc F. Plattner, Liberation Technology: Social Media and the Struggle for Democracy, A Journal of Democracy Book (Baltimore, Md.: Johns Hopkins University Press, 2012), x, http://jhupbooks.press.jhu.edu/ecom/ MasterServlet/GetItemDetailsHandler?i $\mathrm{N}=9781421405674 \& \mathrm{qty}=1 \&$ source $=2 \&$ vi ewMode $=3 \&$ loggedIN=false \&JavaScript $=\mathrm{y}$.

3 Diamond and Plattner, xi.

4 Lauren Etter, "What Happens When the Government Uses Facebook as a Weapon?," Bloomberg.Com, December 7, 2017, https://www.bloomberg.com/news/feat ures/2017-12-07/how-rodrigo-duterteturned-facebook-into-a-weapon-with-alittle-help-from-facebook.

5 McKay Coppins, "The Billion-Dollar Disinformation Campaign to Reelect the President," The Atlantic, February 10,
2020 ,

https://www.theatlantic.com/magazine /archive/2020/03/the-2020disinformation-war/605530/.

${ }^{6}$ Adrian Shahbaz and Allie Funk, "Freedom on the Net 2019: The Crisis of Social Media” (Freedom House, 2019), https://www.freedomonthenet.org/repo rt/freedom-on-the-net/2019/the-crisisof-social-media.

7 "China Is Spending Billions on Its Foreign-Language Media," The Economist, June 14, 2018, https://www.economist.com/china/201 8/o6/14/china-is-spending-billions-onits-foreign-language-media; "China Profile," BBC News, March 6, 2018, sec. Asia, https://www.bbc.com/news/world-asiapacific-13017881.

8 Louisa Lim and Julia Bergin, "Inside China's Audacious Global Propaganda Campaign," The Guardian, December 7, 2018, sec. News, https://www.theguardian.com/news/20 18/dec/07/china-plan-for-global-mediadominance-propaganda-xi-jinping. 
9 “RSF Report: 'China's Pursuit of a New World Media Order' | Reporters without Borders," RSF, March 22, 2019, https://rsf.org/en/reports/rsf-reportchinas-pursuit-new-world-media-order.

10 "10 Most Censored Countries," Committee to Protect Journalists, September 10, 2019, https://cpj.org/reports/2019/o9/10most-censored-eritrea-north-koreaturkmenistan-journalist.php.

11 "China Profile. Freedom of the Press 2017," Freedom House, April 18, 2017, https://freedomhouse.org/report/freed om-press/2017/china.

12 "For Its 70th Anniversary, the Chinese Regime Masquerades as a Champion of Human Rights | Reporters without Borders," RSF, September 26, 2019, https://rsf.org/en/news/its-7othanniversary-chinese-regimemasquerades-champion-human-rights.

13 Qinglian He, The Fog of Censorship: Media Control in China (New York: Human Rights in China, 2008).

14 "Introduction to People's Daily," People's Daily Online, accessed January 28, 2020, http://en.people.cn/90827/90828/
15 Kecheng Fang, "Analysis | What Is China's Propaganda Machine Saying about the Hong Kong Protests?," Washington Post, August 19, 2019, https://www.washingtonpost.com/politi cs/2019/08/19/what-is-chinaspropaganda-machine-saying-abouthong-kong-protests/.

${ }^{16}$ Michael Standaert, "Chinese State Media Downplays Coronavirus as Xi Strikes Positive Tone," The Guardian, January 24, 2020, sec. World news, https://www.theguardian.com/world/2 020/jan/24/chinese-state-mediadownplays-coronavirus-as-xi-strikespositive-tone.

17 Eva Dou and Josh Chin, "People's Daily Chief Warns of 'Historic Mistake' If China Loses Grip on New Media," WSJ (blog), March 21, 2016, https://blogs.wsj.com/chinarealtime/20 16/03/21/peoples-daily-chief-warns-ofhistoric-mistake-if-china-loses-grip-onnew-media/.

18 Christian Shepherd, "Twitter Tally at People's Daily Does Not Add up, Say Researchers," Financial Times, November 23, 2015, https://www.ft.com/content/43319c9o919a-11e5-bd82-c1fb87bef7af. 
19 Anna Arutunyan, The Media in Russia (Maidenhead, Berkshire, England; New York: Open University Press, 2009).

${ }^{20}$ Natalia Roudakova, Losing Pravda:

Ethics and the Press in Post-Truth

Russia, 2017. :168-195

${ }^{21}$ The Putin's "Russian Idea” was reflected in his 1999 Millennium Message. Hill and Clifford (2015) asserted that the problem with the Message was that it illuminated the national goals but did not outline the methods of their achievement. By using "emotion and... historic and cultural symbolism," Putin promised to "rebuild the Russian state, protect Russia's sovereignty, preserve domestic stability and unity, and ensure national security," but never mentioned how he would go about it (Fiona Hill, Clifford G Gaddy, and Brookings Institution, Mr. Putin: Operative in the Kremlin, 2015, http://public.eblib.com/choice/publicfu llrecord.aspx? $\mathrm{p}=4321748$.).

22 “Финансирование СМИ из бюджета предложено увеличить на треть [State media budget proposed increase by a third]," Interfax.ru, September 26, 2019, https://www.interfax.ru/russia/678102. ; Фарида Рустамова [Farida
Rustamova], “Бюджет государственных СМИ в России вырастет на 2,5 млрд рублей [Russia's state media budget to increase by $2.5 \mathrm{bn}$ rubles]," ВВC News Русская служба [BBC News in Russian], May 26, 2017, sec. Новости, https://www.bbc.com/russian/news40062877; Gabrielle Tetrault-Farber, "Looking West, Russia Beefs Up Spending on Global Media Giants," The Moscow Times, September 23, 2014, https://www.themoscowtimes.com/201 4/o9/23/looking-west-russia-beefs-upspending-on-global-media-giantsa39708.

23 "Foreign Policy Concept of the Russian Federation (Approved by President of the Russian Federation Vladimir Putin on November 30, 2016)," The Ministry of Foreign Affairs of the Russian Federation, December 1, 2016, https://www.mid.ru/foreign_policy/offi cial_documents//asset_publisher/CptICkB6BZ29/conte nt/id/2542248?p_p_id=101_INSTANC E_CptICkB6BZ29\&_101_INSTANCE_C ptICkB6BZ29_languageId=en_GB. 
24 Simon Shuster, "Inside Putin's Media Machine," TIME.Com, March 5, 2015, http://time.com/rt-putin/.

25 “About RT,” RT International, accessed December 13, 2018, https://www.rt.com/about-us/.

${ }^{26}$ Georgi Beltadze, "Mark Voyger:

Russian Hybrid Warfare Can Still Bring Surprises in the Future," Estonian news - news.postimees.ee, June 18, 2018, https://news.postimees.ee/4505726/ma rk-voyger-russian-hybrid-warfare-canstill-bring-surprises-in-the-future.

27 Mason Clark. Institute for the Study of War, "Russian Hybrid Warfare," September 2020, http://www.understandingwar.org/repo rt/russian-hybrid-warfare; http://www.understandingwar.org/sites /default/files/Russian\%20Hybrid\%20W arfare\%20ISW\%20Report\%202020.pdf. 28 "The Mueller Report, Annotated," Washington Post, July 23, 2019, https://www.washingtonpost.com/grap hics/2019/politics/read-the-muellerreport/; "Highlights From The Mueller Report, Annotated," NPR.org, April 18, 2019, https://www.npr.org/2019/04/18/7089 65026/highlights-from-the-muellerreport.

29 The Select Committee on Intelligence, United States Senate, "Report on Russian Active Measures Campaigns and Interference in the 2016 U.S. Election. Volume 1: Russian Efforts Against Election Infrastructure with Additional Views" (Washington D.C.: U.S. Senate, July 2019), https://www.documentcloud.org/docu ments/6214293-Report-Volume1.html.

30 "Statement by NCSC Director William Evanina: Election Threat Update for the American Public," Office of the Director of National Intelligence, August 7, 2020, https://www.dni.gov/index.php/newsro om/press-releases/item/2139statement-by-ncsc-director-williamevanina-election-threat-update-for-theamerican-public.

${ }^{31}$ Ellen Nakashima, "Fewer Opportunities and a Changed Political Environment in the U.S. May Have Curbed Moscow's Election Interference This Year, Analysts Say," Washington Post, November 17, 2020, https://www.washingtonpost.com/natio nal-security/russia-failed-to-mount- 
major-election-interference-operationsin-2020-analystssay/2020/11/16/72c62boc-188o-11eb82db-6ob15c874105_story.html; Julia Carrie Wong, "Putin Could Only Dream of It': How Trump Became the Biggest
Source of Disinformation in 2020," The Guardian, November 2, 2020, sec. US news, https://www.theguardian.com/usnews/2020/nov/02/trump-us-electiondisinformation-russia. 